\title{
Material Culture: A Review of the 2013 Oxford Symposium on Food and Cookery
}

Máirtín Mac Con lomaire

Technological University Dublin, mairtin.macconiomaire@tudublin.ie

Follow this and additional works at: https://arrow.tudublin.ie/tfschafart

Part of the Arts and Humanities Commons, and the Social and Behavioral Sciences Commons

\section{Recommended Citation}

Mac Con lomaire, M. (2014). 'Material Culture: A Review of the 2013 Oxford Symposium on Food and Cookery'. Journal of Culinary Science and Technology. Vol. 12, No. 3, pp. 191-195, DOI: 10.21427/d76f3p

This Article is brought to you for free and open access by the School of Culinary Arts and Food Technology at ARROW@TU Dublin. It has been accepted for inclusion in Articles by an authorized administrator of ARROW@TU Dublin. For more information, please contact arrow.admin@tudublin.ie, aisling.coyne@tudublin.ie, gerard.connolly@tudublin.ie.

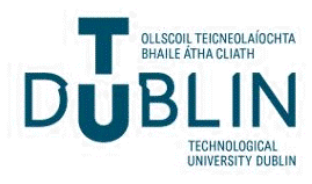




\section{Material Culture: A Review of the 2013 Oxford Symposium on Food and Cookery}

The focus of this year's Oxford Symposium on Food and Cookery was on the stew stove not the stew; the knives not the meat; the salt pots or 'nefs' rather than the salt; the 'chasen' not the tea; the plates (whether pewter, ceramic, delftware, china, silver or gold) but not their food contents. We were gathered to discuss associated material culture of food and cookery rather than the perishable ephemeral substance that usually concerns this gathering now in its thirty-first year. The study of food and cookery is a serious subject. The World Health Organisation estimates that 1.5 million deaths are caused annually by smoke generated from cooking. Indeed, one of the problems with stew stoves, as highlighted by Pat Reber in a paper on the Federal-era American kitchen, was carbon monoxide poisoning. Marie-Antoine (Antonin) Carême, one of the world's most influential chefs, died aged forty-nine, burnt out by the flame of his genius and the fumes of his stoves. Some articles of material culture such as the pestle and mortar may have a 10-20,000year history, yet other common objects such as the double sided vegetable peeler, may date from as recently as the past twenty years. Newer objects associated with Modernist Cuisine are constantly being invented and imagined, and Ken Albala in his paper and presentation shared some of his own creations and imaginings with the gathered symposiasts. Bee Wilson pointed out that there has been an imbalance to date in food scholarship favouring ingredients over techniques, utensils and tools, illustrated by the fact that there is not a single reference to kitchens in The Cambridge World History of Food! She also noted, however, that archaeologists at least have embraced (culinary) material culture in coining the term 'Beaker People'.

So, what did the 220 chefs, food historians, writers, scientists, anthropologists and general foodies learn from the weekend's discussion on material culture and the informal discussions over meals? What new knowledge or connections were grasped? What new collaborations will come from the event? The answers might be divided neatly into 'Tools, Table manners, and Technology', or to push it even further 'Teeth'. They are all interlinked actually as we shall see.

The knife, one of the earliest tools to come into use, has allowed man to cut, chop, and even kill! Table manners, it seems, developed from the fear of being stabbed by one's dining neighbour. David Sutton spoke of the habit of having a friend stand guard beside you as you drank wine to protect you from attack whilst in a vulnerable position. To allay this fear of stabbing, table knives were developed with rounder edges that were less sharp. In China, it was fear of violence towards the Emperor that led to the replacement of knives with chop sticks! This development and the resultant practice of presenting their food in smaller bite-size pieces led to a change in the anatomical structure of the denizens of China that predates that of Europeans by many centuries. Anthropologists have linked the development of the overbite in our dental anatomy to the practice of eating smaller bite-size morsels of food. The overbite emerged in China 900 years ago due to their use of chopsticks. This anatomical change did not occur in Europeans until the early modern period. It corresponded with a change in dining habits when the use of forks became popular first in Italy and Byzantium and gradually throughout the courts of Europe. Joan Fitzpatrick discussed the 
emerging distinction between napkins (literally little cloths) and handkerchiefs (literally hand cloths) during the early modern period, and their use to connote distinctions in manners, femininity and food. Napkins were especially important before forks came into common use. Erasmus of Rotterdam stipulated in his 1530 book on manners that if a napkin was not provided, the table cloth may be used. The gradual use of forks, which kept the fingers clean, coincided with the rise of books on etiquette and table manners.

The place at table of the 'nef' and the 'cadenas', the blunting of knives, the rise of the fork and the consolidation of food hierarchies all naturally accompanied the new interest in etiquette. David Sutton outlined in his paper the key features of the table etiquette of a highly stratified society between 1550 and 1750 and also highlights the hierarchy of foods associated with kings, lords, dukes, down to the servants and the poor. Garlic, mushrooms, sprats and gooseberries were associated with the poor and would never be served at an elite table. Mushrooms were called 'l'excrément de terre' as they emerged straight from the soil. How times and fashions change in food, technology and texture! Fine textured food was once the domain of the aristocracy, but nowadays the cachet is for hand-made chunky artisanal food to show that no technology was employed in its preparation or for food that has been foraged locally. Another point of table etiquette in the early modern period included never discussing the food served. This particular rule was blatantly ignored in Oxford this July during the various meals served over the weekend, which included Ethiopian, Brazilian and Middle Eastern repasts, not to forget Stevie Parle's spice feast on the Friday evening, when guests got to create their own spice mixes with pestles and mortars.

Papers covered and traversed a number of centuries and while her latest book is called Consider the Fork, Bee Wilson, in her intriguing talk, asked us to consider the spork! A 'spork' is a hybrid spoon and fork or as Wilson describes it a 'jointed tool' similar to a camera phone. An earlier jointed tool, the 'splayd' or 'splade' (spoon with a blade), which in sets were popular Australian wedding gifts in the 1950s and 1960s was not discussed! Another jointed tool discussed by Ken Albala was the 'nork' - a hybrid knife and fork which it appears is very practical for people who have lost a limb. Products have been designed in recent decades in the industrial food sector that require no utensils whatsoever. Albala argues that an entire generation may be completely bereft of the manual dexterity demanded for the successful engagement with the knife and fork as utensils, plastic or otherwise, become superfluous.

In the highest echelons of three star Michelin restaurants, however, the disciples of modernist cooking are embracing both technology and material culture to create theatre in the dining room. Jeremy Medley discussed techniques such as anti-griddles (salt plate dipped in liquid nitrogen), and displayed a variety of utensils and material culture such as mini crystal teapots, tins of beans that contain candyfloss or lavender spray. He discussed how chefs such as Ben Spalding are encouraging their customers to lick the bricks that their food was served on! Diners were getting to make their own lollipops at the table. This interaction, he suggested, leads to conversation, and gets people talking. Whereas the Gueridon service of old was interactive, it was stiff and formal. This has been 
replaced by fun, novelty, nostalgia and the informality of self service. One asks if there are any vestiges of table etiquette left in this world of iPhones, twitter and bloggers. Have Generation $X$, and the future Generation $Y$ and $Z$ lost the art of conversation? Do they need to be constantly entertained? Is dry ice and lollipop making the $21^{\text {st }}$ century's version of the medieval soteltie?

The range and scope of material culture associated with food production and service was quite dramatic, ranging from Len Fisher's simple 'spirtle' for stirring porridge (ideally at 1.4 revolutions per second) to Carolin Young's visual presentation of the most amazing collection of silver soup tureens and olio pots shaped like boars heads, coiled eels, cauliflowers, or baskets of Portuguese fish, many made by skilled Huguenot silversmiths. Somewhere between both ends of the spectrum lay Mongolian milk spoons, Belgian beer glasses, Indian thali dishes, James Bond cocktail shakers, New York refrigerators, Italian food processors and 3D food printers. From medieval 'Nefs' to futuristic 'Digital Gastronomy', this year's papers and presentations engaged energetically and creatively with the theme of Material Culture relating to food and drink. Are you familiar with the science behind stirring, mixing and shaking? Have you heard of the Brazil nut effect? Did you know that engineers have been studying turbulence extensively to devise rules for the stirring of different food mixtures? A reading of Len Fisher, Janet Clarkson and Alan Parker's paper will inform you how to make the perfect martini and provide entertaining answers to the above questions.

The title of Joan Smith's lecture 'Eating history: the perishable art of food' encapsulated the ephemeral nature of food. She discussed how food perishes but art remains. Some material culture also remain, but as Barbara Ketchum Wheaton has often noted about libraries and book collections, what is commonest and most used is often also what is discarded and least likely to appear in special collections or archives. As women's magazines, cheap novels and schoolbooks are seldom preserved for posterity, neither are wooden spoons, every day glassware or plates. In 200 years time, will there be special collections and catalogues of 'Habitat' crockery as there are now for 'Sèvres' porcelain? Darra Goldstein spoke of the transformative power of objects. Vessels, such as the chalice in the Roman Catholic rite in which wine is transformed into the blood of Christ, can have symbolic power. Material culture is culturally specific and can carry symbolic freight. Immigrants often bring tools with them from their home country that have little or no monetary value but are brimming with symbolic value. Amy Trubek reiterated the ephemeral nature of food and cooking, pointing out that tradition and practices are constantly disappearing without us even noticing. New practices and technology have even permeated what we may perceive as one of the richest gastronomic cultures. It appears that the 'Bimbi' food processer is transforming Italian life and that the romantic idea of the Italian kitchen may now merely be a myth. As an anthropologist, Trubek notes that the landscape of cooking requires broad strokes and fine details. She asks 'does the tool make the identity or the way you use the tool?' Her illustration of the level of assumed knowledge evident in cooking instructions was heart warming and eye opening. She showed a video of a man asking his young daughter to squeeze a lemon. The young girl took the whole lemon and smashed it down on the juicer without first cutting it in half! I recall a Dublin chef telling me of his first encounter with a banana in the years following the end of World War II; he tried to eat it without knowing it needed peeling! We cannot assume prior knowledge of these simple procedures or indeed of table manners, 
not to mention eating and cooking practices which are often culturally shaped and require prior learning either through observation or instruction.

From Picnic baskets, to the New York City's Automat; from First World War Trench Fare to Turkish Coffee; from Baghdad Kitchens to how kitchen knives have become the new 'bling'; from coconut scrapers to Bovril; from how to make solar cooking global to elite consumption trends in Georgian Ireland; from Korean folk potters to a prize-winning paper on pottery in prehistoric Oxfordshire; from sugar sculptures in Italian court banquets to equipment used by street food vendors in Istanbul; from visual evidence of table manners to Mooncake tin boxes, cow creamers and 'cudsters'; from magical Brazilian cookery pots to the Talmudic 'qederah', a better insight into the material culture associated with food and cooking can be gleaned by purchasing the forthcoming proceedings of the Oxford Symposium 2013 - which will definitely be worth its salt! 